\title{
Professional Competencies of Cuban Specialists in Intensive Care and Emergency Medicine
}

\author{
Pedro L. Véliz-Martínez MD MS, Ana R. Jorna-Calixto MD MS, René Oramas-González MD PhD
}

\begin{abstract}
INTRODUCTION The quality of medical training and practice reflects the competency level of the professionals involved. The intensive care and emergency medicine specialty in Cuba has not defined its competencies.

OBJECTIVE Identify the competencies required for specialty practice in intensive care and emergency medicine.

METHODS The study was conducted from January 2014 to December 2015, using qualitative techniques; 48 professionals participated. We undertook functional occupational analysis, based on functions defined in a previous study. Three expert groups were utilized: the first used various group techniques; the second, the Delphi method; and the third, the Delphi method and a Likert questionnaire.
\end{abstract}

\section{INTRODUCTION}

To improve patient care, health systems worldwide have had an ongoing concern with health care professionals' competencies, functions, and job performance, and have called for medical schools to educate professionals to adequate levels of ability and performance.[1]

Professional competencies have been defined as the set of knowledge, procedures, attitudes and values that have concrete job results in a specific work environment. These competencies involve socioaffective, cognitive, psychological, sensory and motor abilities, expressed as knowing, knowing how to do, and knowing how to be, so that the professional knows how to act to solve problems and complete tasks, functions and responsibilities in professional practice.[2-7]

There have been many projects, meetings, events and statements on this topic, and various models have been proposed to address the development of competencies in medical education and how they relate to patient care and the workplace. Several countries have adopted competency-based training in their universities, and organizations and centers have been created for its study.[8-13] In the intensive care specialty, several studies have identified competencies. Some of the most important are Roca's study,[4] the CoBaTrICE project and the Multisociety Task Force Recommendations.[14,15]

In Cuba, regulations have been approved to identify job competencies,[16-18] and several studies have been conducted by the National School of Public Health and the Medical University of Havana (UCMH).[2,3,19,20] The Ministry of Public Health (MINSAP) created a national competency and performance commission, which began the process of defining competencies in seven specialties.[21] The intensive care and emergency medicine (IEM) specialty was not among the first seven selected for competency definition in this process, but two national workshops were held to develop the IEM specialty, in which 60 eminent professionals agreed on the need
RESULTS A total of 73 specific competencies were defined, grouped in 11 units: 44 in the patient care function, 16 in management, 7 in teaching and 6 in research. A competency map is provided.

CONCLUSIONS The intensive care and emergency medicine specialty competencies identified will help improve professional standards, ensure health workforce quality, improve patient care and academic performance, and enable objective evaluation of specialists' competence and performance.

KEYWORDS Clinical competency, competency-based education, professional education, intensive care, emergency medicine, urgent care, continuing medical education, curriculum, medical residency, Cuba

to define IEM competencies and to modernize Cuba's IEM residency program with a competency-based curriculum. $[1,22,23]$

The purpose of this study was to identify specific professional competencies of IEM specialists, thus helping to improve professional profile and job performance.

\section{METHODS}

Study type and participants A developmental study was conducted from January 2014 through December 2015, using qualitative techniques. Empirical methods used were surveys and expert consultations. The research builds on previous work by Véliz that defined specific functions and procedural skills required of IEM specialists.[23]

A purposive maximum-variation sampling strategy was used to select 48 professionals for different stages of the study, taking into account their experience and ability to provide authoritative and competent judgments.[24,25] Participants included members of the National IEM Expert Group; members of the national governing board of the Cuban Society of Intensive Care and Emergency Medicine; and members of the IEM residency and specialty advisory committee. It also included heads of ICUs; IEM professors; officials of MINSAP's Division of Urgent Care, Emergency Medicine and Transplantation; academic deans and vice deans of faculties offering IEM training; directors and assistant directors of hospitals with intensive care units, critical care departments and emergency rooms; and managers of mobile medical emergency units.

Data sources and collection Information collection instruments were developed for both the surveys and expert consultations, and databases were created for statistical processing.

\section{Definitions}

IEM specialist Physician who has successfully completed the IEM medical residency or who has met the requirements for the 
title of second-degree specialist (a Cuban higher-level specialty credential) in IEM after being accredited in another medical specialty.[26]

Professional competencies Set of knowledge, skills, attitudes and values used in a specific work environment to solve a concrete problem in the practice of a profession.[7]

Specific professional competencies Those that all professionals require to practice their profession, depending on the area, service or specialty. As these are gradually acquired, specialists increase their expertise.[19]

IEM specialists' professional competencies Set of knowledge, skills, attitudes and values that determine IEM specialists' practice and are used in their work environment, with concrete job results.[7]
Figure 1: Methodology for defining professional competencies of specialists in intensive care and emergency medicine

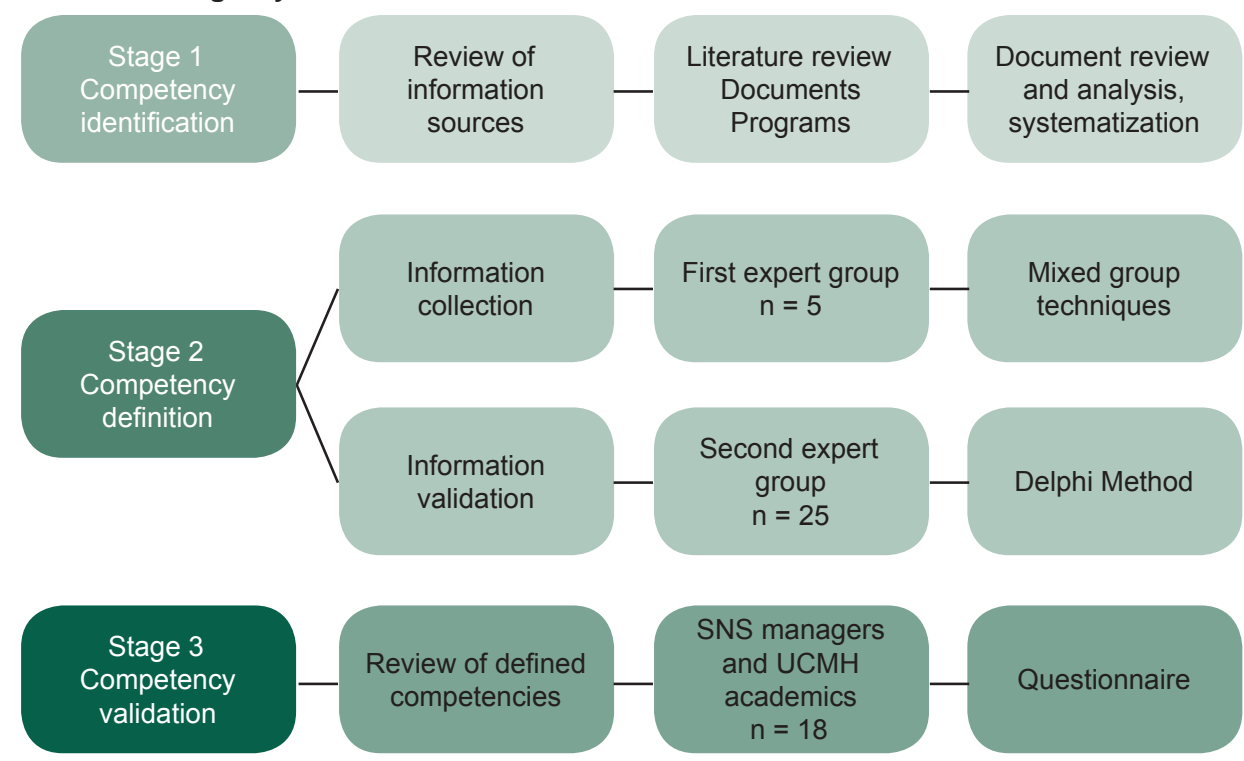

SNS: National Health System

UCMH: Medical University of Havana
Key purpose Definition of what the occupation purports to achieve.[27] In the health care professions, this is care in the health-disease process.[28]

Functions or competencies Definitions based on the key purpose, and related to the basic and most general functions of the specialty, stated in its graduate profile.[22] In IEM, four functions have been defined: patient care, management, teaching and research.[23]

Competency unit (CU) A set of productive functions that can be performed by a person in a particular job. CUs are made up of various achievements that must be attained for the specific function to be considered fulfilled.[28]

Competency element (CE) An action, behavior, or result that professionals must demonstrate.[27]

Functional competency map A table showing the process for successively categorizing competencies. It begins by formulating the key purpose of an area for analysis, continues by identifying competency units, and is completed by specifying the competency elements a specialist should be able to perform.[28]

Study design Three groups of experts were consulted to define IEM specialists' competency areas, competency units and specific competency elements, following steps described in detail by Véliz,[1,23] with some modifications.

The algorithm used was developed in the three stages (Figure 1).

Stage 1. Identification of IEM specialists' professional competencies

- document analysis and systematization of definitions, focuses and trends in professional competencies and work performance

- state of the art of IEM competencies worldwide

Stage 2. Competency definition

- Information collection: This was done with a first group of five IEM experts who had participated in the previous study[1,2,3] and met the criteria: $\geq 10$ years of IEM practice, involved in direct care during the study, teaching appointment of at least assistant professor level or higher with satisfactory evaluations, master's degree or doctorate, second-degree specialization in IEM and experience in research.

This group performed its work in several face-to-face sessions, alternated with other techniques, such as oral and written brainstorming[25] on a discussion list called Competenciasmie, created on Infomed (Cuba's digital health information network) for working via email. In the end, a list of CEs was obtained, the CEs were grouped into CUs, and a map of specific IEM competencies was created.

- Information validation: This was conducted with a second expert group of 25 professionals from across Cuba, of whom 16 had participated in the previous study. Nine specialists left the group for various reasons, and were replaced by professionals who had qualified for the previous study, but had not participated in it.[23] The nine specialists who joined the group received individual orientation on professional competencies. All participants met study requirements:

- $\geq 15$ years practicing medicine

- $\geq 10$ years practicing IEM at different care levels, and currently providing direct specialty care

- Second-degree specialization in IEM

- Teaching appointment at assistant professor level or higher, with satisfactory evaluations

- MS in urgent care or other IEM-related degree, and/or PhD

- History of performing patient care, teaching and research duties, with satisfactory evaluations

- Participation on year-end exam juries and state specialty exam boards

All these professionals had an average competence coefficient[1,20] of 0.94 , higher than in the previous study.[23] 
The Delphi method was applied in three rounds:

- Round 1: Via email, participants were sent the list of specific competencies determined by the first group, and were offered a chance to give a dichotomous answer (agree/disagree) for each proposed CU and CE, and add other competencies or propose any modifications they considered necessary. This design allowed calculation of the percentage of accepted or unaccepted competencies, and addition of others that had thus far not been identified. The cutoff for determining consensus was $80 \%$, adopted as the standard of approval for each proposed CU and CE.[24,29] Experts were contacted by email, telephone or in person to discuss their responses and ensure they had been clearly and accurately understood. Questionnaire responses were then reviewed by the author group and a second questionnaire incorporating all contributions was prepared.

- Round 2: The group received the resulting list of specific competencies, showing group response percentages, comments, and new proposals and modifications (repetitions deleted, as were details that could be included in competency standards in later studies). This allowed experts to reassess their opinions after reading other group members' views. To complete this round, the authors performed a logical and grammatical analysis of responses that met the $80 \%$ threshold, deleting those that failed to meet it and eliminating repetitive or redundant proposals.

- Round 3: This round allowed increased consensus among the experts (by identifying indicators with $85 \%$ or higher agreement). A final report was prepared, which was sent to each expert along with a letter of thanks.

\section{Stage 3. NHS managers and UCMH academics}

As in the previous study,[23] a third group of 20 professionals was convened, consisting of policy, management, academic and methodological decisionmakers in the SNS and UCMH. This group included directors and deputy directors of hospitals with intensive care units, critical care departments and emergency rooms, as well as managers of mobile medical emergency units. In addition to their position or job responsibility, all met study requirements: $\geq 20$ years in medical practice, first- or second-degree specialization, university teaching appointment, a master's degree or doctorate, and a competence coefficient $>0.8$. All had a competence coefficient of 0.9 or greater. Only three had participated in the previous study. Two members did not complete the Delphi process and were excluded from the study.

The purposes of the study were explained to all, as were participants' contributions and roles within it. They were asked to join a group using the Delphi method. To initiate the process, the CUs and CEs defined by the previous groups were listed in a document (questionnaire), and a Likert-type rating scale was applied, using five columns ordered by degree of importance or priority. [23] Two rounds of consultation were held.

Data analysis and management Results were collected in Excel and SPSS 21 for Windows databases. Results were displayed as absolute and relative frequencies in contingency tables, with competencies as rows and ratings as columns (accepted/not accepted in the first two Delphi rounds). Ratings from the final
Delphi round were on an ordinal scale of: unimportant, somewhat important, important, very important and essential, numbered from one to five in the same order.

Ethics Participants' anonymity, confidentiality and written informed consent were ensured. The study was approved by the Ethics Committee of UCMH's Comandante Manuel Fajardo Medical Sciences Faculty.

\section{RESULTS}

The first expert group performed a functional occupational analysis of the specific IEM specialist functions described by Véliz[24] with the following results by function:

- patient care, 48 CEs grouped in 7 CUs

- management, 17 CEs in 3 CUs

- teaching, 6 CEs in $1 \mathrm{CU}$

- research, 6 CEs in $1 \mathrm{CU}$

The second expert group used the Delphi process to assess the specific competencies and competency map determined by the first group. In the first round, it confirmed that all CUs and CEs had obtained $>92 \%$ approval (above the $80 \%$ minimum standard). No new CUs were proposed to add to the seven in the patient care function, although it was suggested that two CUs be merged, which lowered the number to six. There were 83 proposed changes to the CEs, consisting of 66 wording changes, 11 new CE proposals, 3 mergers, 2 deletions and 1 division into several CEs.

After Round 2, there were 35 proposed changes: 21 CE wording changes, 8 new CE proposals, 3 mergers and 1 separation. The final list at the end of Round 3 contained 73 CEs in 11 CUs: 44 CEs in patient care, grouped in 6 CUs; 16 CEs in management, in $3 \mathrm{CUs} ; 7$ in teaching, in $1 \mathrm{CU}$; and 6 in research, in $1 \mathrm{CU}$.

Table 1 displays the responses of the third expert group concerning the CUs' importance to IEM as a specialty. The 18 professionals ranked the $11 \mathrm{CUs}$ and $73 \mathrm{CEs}$ defined by the previous groups as essential 896 times (59.3\% of 1512 possible answers), very important 514 times (34\%), and important 102 times (6.7\%). None of the CUs or CEs were rated not very important or unimportant, with ratings basically divided between the very important and essential categories.

Table 2 displays the map of CUs and CEs defined by the study.

Table 1: Expert ratings of importance of specific IEM competencies ${ }^{1}$

\begin{tabular}{|l|r|r|r|r|r|r|}
\hline \multirow{2}{*}{ Function } & \multicolumn{6}{|c|}{$\begin{array}{c}\text { Competency rating } \\
\text { n (\%) }\end{array}$} \\
\cline { 2 - 8 } & \multicolumn{7}{|c|}{ Essential } & Very important & \multicolumn{2}{|c|}{ Important } \\
\cline { 2 - 8 } & \multicolumn{1}{|c|}{$\%$} & $\%$ & $n$ & $\%$ & $n$ & $\%$ \\
\hline Patient care & 538 & 59.8 & 310 & 34.4 & 52 & 5.8 \\
\hline Managerial & 212 & 62.0 & 93 & 27.2 & 37 & 10.8 \\
\hline Teaching & 79 & 54.9 & 56 & 38.9 & 9 & 6.3 \\
\hline Research & 67 & 53.2 & 55 & 43.7 & 4 & 3.3 \\
\hline Total & 896 & 59.3 & 514 & 34.0 & 102 & 6.7 \\
\hline
\end{tabular}

${ }^{1}$ Both competency units and competency elements

${ }^{2}$ Number of times competency received this rating (maximum possible 1512) IEM: intensive care and emergency medicine 
Table 2: Functional competency map for intensive care and emergency medicine

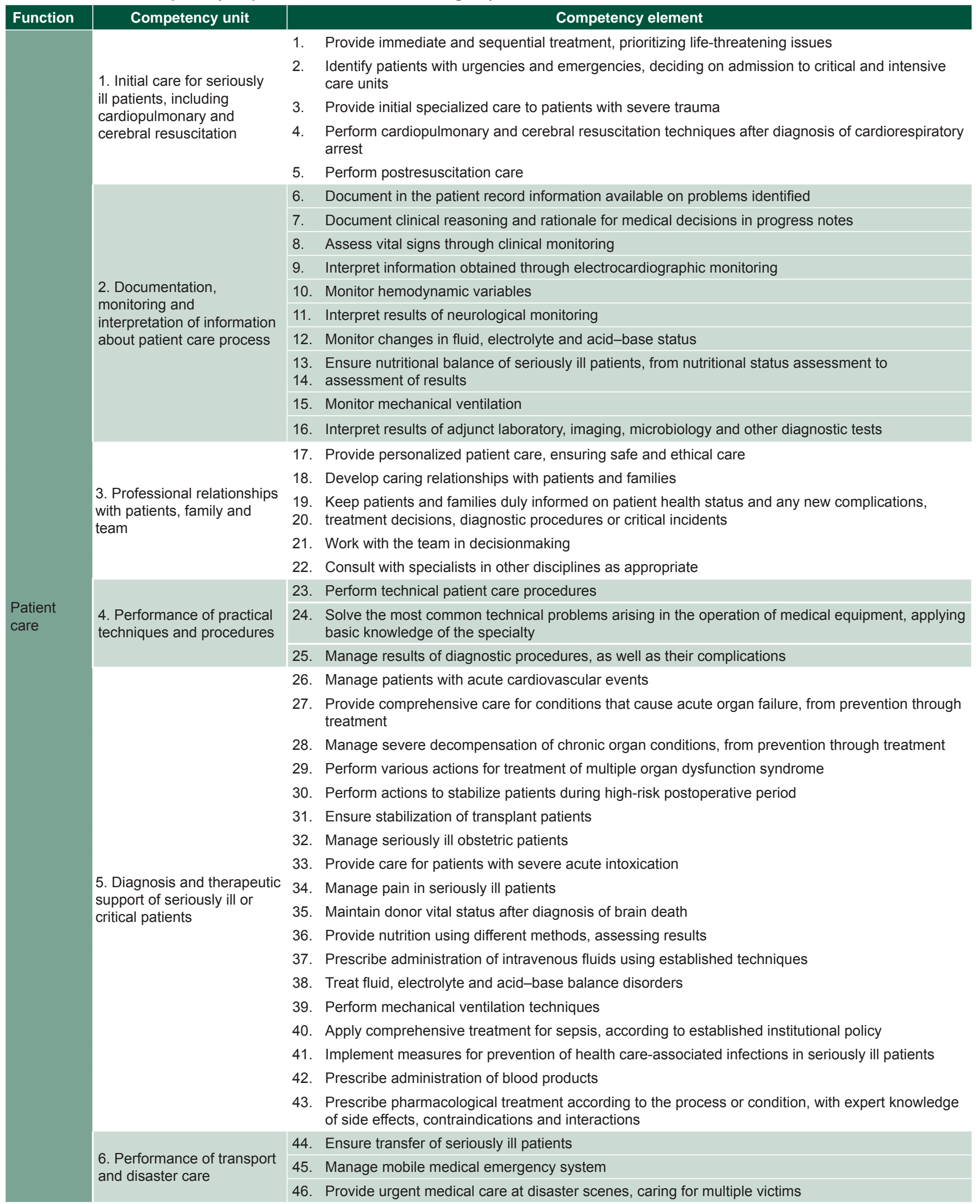


Table 2: Functional competency map for intensive care and emergency medicine (cont'd)

\begin{tabular}{|c|c|c|}
\hline Function & Competency unit & Competency element \\
\hline \multirow{15}{*}{$\begin{array}{l}\text { Manage- } \\
\text { ment }\end{array}$} & \multirow{5}{*}{$\begin{array}{l}\text { 1. Organizational and } \\
\text { functional management of } \\
\text { units that care for seriously } \\
\text { or critically ill patients }\end{array}$} & 1. Manage organizational and functional structure of care unit \\
\hline & & 2. Follow guidelines and norms of care unit and institution \\
\hline & & 3. Apply norms for admission to and discharge from care units \\
\hline & & $\begin{array}{l}\text { 4. Manage patient care, academic and administrative activities in the seriously ill patient care process, } \\
\text { according to management principles }\end{array}$ \\
\hline & & 5. Perform internal audits \\
\hline & \multirow{6}{*}{$\begin{array}{l}\text { 2. Administration of human } \\
\text { and material resources in } \\
\text { care of seriously or critically } \\
\text { ill patients }\end{array}$} & $\begin{array}{l}\text { 6. Organize patient care in unit, according to scope of responsibility and service needs } \\
\text { 7. Administer material resources, according to scope of responsibility and service needs }\end{array}$ \\
\hline & & 8. Supervise work of nurses, other professionals and technicians in unit \\
\hline & & 9. Monitor work plans to ensure program implementation \\
\hline & & 10. Evaluate competencies in professional performance \\
\hline & & 11. Plan individual and collective professional development \\
\hline & & 12. Participate in strategies for selection, training and employment of human resources \\
\hline & \multirow{4}{*}{$\begin{array}{l}\text { 3. Monitor quality of care } \\
\text { and safety for seriously ill } \\
\text { patients }\end{array}$} & 13. Monitor quality-of-care indicators for seriously ill patients \\
\hline & & 14. Participate in quality committees, evaluating results of patient care activities \\
\hline & & 15. Implement patient safety programs \\
\hline & & 16. Ensure compliance with patient rights program, according to ethical principles \\
\hline \multirow{7}{*}{ Teaching } & \multirow{7}{*}{$\begin{array}{l}\text { Perform teaching, } \\
\text { educational and training } \\
\text { activities }\end{array}$} & $\begin{array}{l}\text { 1. Perform teaching activities through in-service education, according to established profiles and } \\
\text { objectives }\end{array}$ \\
\hline & & 2. Develop instructional skills for teaching \\
\hline & & 3. Use teaching methods that encourage active learning \\
\hline & & 4. Demonstrate ability to teach use of clinical-epidemiological method in seriously ill patients \\
\hline & & 5. Evaluate the teaching-learning process using different techniques \\
\hline & & 6. Design health education programs, based on the learning needs of professionals and technicians \\
\hline & & 7. Demonstrate ability to use information and communication technologies \\
\hline \multirow{6}{*}{ Research } & \multirow{6}{*}{$\begin{array}{l}\text { Conduct specialty-related } \\
\text { scientific research }\end{array}$} & $\begin{array}{l}\text { 1. Apply methodological principles of scientific research to conduct clinical research along identified } \\
\text { lines of research }\end{array}$ \\
\hline & & $\begin{array}{l}\text { 2. Use statistical tools and bibliographic references, including foreign-language literature, to develop } \\
\text { research, patient care and teaching activities }\end{array}$ \\
\hline & & 3. Communicate research results in various formats \\
\hline & & $\begin{array}{l}\text { 4. Use results of scientific research to improve patient care and achieve higher-level scientific and } \\
\text { research appointments }\end{array}$ \\
\hline & & 5. Organize scientific and research activities in the specialty \\
\hline & & 6. Participate in implementation of clinical trials \\
\hline
\end{tabular}

\section{DISCUSSION}

Defining professional competencies for IEM was an important challenge because of the study's potential impact on the specialty's present and future practice, and because of the need to clearly define what constitutes an intensive care specialist in Cuba, as well as to set targets for levels of training, competence and performance to improve quality as physicians proceed through specialty training along its path to professionalization. [30,31]

The competencies obtained are tools for human resource development and a basis for training, mentoring and curriculum improvement to enhance quality and safety of patient care. They are the starting point for performance appraisal and a service quality accreditation system. Performance improvement is a deliberate process carried out through specialists' systematic integration of new knowledge and tools as the specialty evolves.

Competencies have been examined and classified from a number of perspectives; we adopted a classification based on generic and specific competencies.[7] Our focus in this study was on defining specific professional competencies for IEM specialists in Cuba. Our approach to defining specific patient care competencies was tailored to medical care of the seriously ill patient using the clinical-epidemiological method,[32,33] from initial patient care in urgent and emergency situations, to care for patients in critical stages of disease, and over the spectrum of prevention, diagnosis, treatment and rehabilitation.

Patient care competencies include documentation, monitoring, followup, development and interpretation of clinical, laboratory and imaging data, analysis and integration of new situations; carrying out IEM techniques and procedures;[24] diagnosis and therapeutic support of patients with serious or critical illness; disaster transport and care; and maintaining professional relationships with patients, families and the health care team, based on solid ethical foundations.[34,35]

We believe that the patient care competencies identified here are both an expression and a consequence of the Cuban health care 
model, in which IEM provides continuous, progressive care to patients with clinical or surgical urgent care or emergency needs of any origin. As the patient moves through different scenarios in the care network, intensivists must be prepared to work in these scenarios and dedicate all their time to highly specialized care and treatment.[22] Since patient care tasks are the core of the specialty, it is only to be expected that the majority of specific competencies identified relate to the patient care function. Other studies in intensive care medicine have had similar results. $[4,14,15]$

Second in number to patient care competencies are management CUs and CEs which provide organizational, followup, managerial and monitoring support for patient care and academic processes and activities, as well as for management activities themselves in various health service components. These competencies build on the management functions defined in the previous study,[23] which considered administration a social science that uses planning, organizing, managing, coordinating and monitoring of activities to marshal material and human resources to meet organizational objectives.[36] Management competencies also involve analysis of quality indicators and monitoring of human and financial resources, as well as requiring compliance with regulations, protocols and guidelines in medical care through internal audits and rigorous quality control. For health administration, quality health care and patient safety programs are two vital components.

Seven teaching CEs were determined, all under a single CU. These include conducting teaching and training activities for professionals and employees within facilities, through use of teaching skills, active learning methods, evaluations and designing health education programs, all of which contribute to professional development and continuing education.[3] The competency in use of information and communications technologies deserves special attention, as these technologies offer an ideal framework for sharing and disseminating knowledge and supporting training, research and innovation in IEM.[37]

Six research CEs were determined, grouped under a single CU: application of methodological principles of scientific research to conduct clinical research; use of statistical tools, bibliographical references, including foreign-language literature, to develop research, patient care and teaching activities; communicating results in different formats; organizing scientific activities; and participating in clinical trials, all of which IEM specialists should use to build their scientific and research skills and improve patient care, creating added value for both themselves and their work settings. Intellectual capital and human resources now constitute prime competitive advantages for organizations.[38]
Competencies have not been explicitly stated in Cuba's IEM specialty curriculum,[39] so there is no basis for comparison with the ones developed in this study, and very few studies have fully identified specific professional competencies in other medical specialties in Cuba.[10,40] Nor do we intend to draw comparisons with intensive care competency studies conducted in Europe[4,14] and the United States,[15] since results are influenced by differing contextual factors, such as health care and training scenarios, and economic and technological development.[7] Furthermore, Cuba's IEM specialty combines intensive care, urgent care and emergency care specialties, which are considered separate specialties in some other countries.[22]

One of the study's constraints is that the competencies it identified have not yet been broken down into their essential components, including knowledge, skills, procedures and values, a task for further research. Nevertheless, the study is timely, because it corresponds with recently approved guidelines for Cuba's economic and social policy.[41] It is also innovative because of its comprehensiveness and focus on determining IEM specialist competencies, emphasizing key principles such as in-service education; integration of teaching, patient care and research; and encouragement of a tutorial education process for residents and ongoing postgraduate professional development.

Identifying IEM specialty competencies is crucial to enabling performance assessment and evaluation of job performance and assessment of specialists' suitability to practice; it also provides a guide for rational distribution of specialists in the various occupational IEM profiles in Cuba and countries where Cuba provides medical collaboration.

From a technical standpoint, the methodology used in the study may be informative for developmental research to determine competencies in other specialties.

\section{CONCLUSIONS}

The specific professional competencies of IEM specialists were identified using a scientific method based on consultation with experts. Defining specific competencies in intensive care and emergency medicine is a theoretical, practical, methodological and social contribution that can be used for future curriculum reform and evaluation of specialist performance. It thus constitutes a tool for improving IEM management, training, research, and, ultimately, patient care quality in Cuba. -1 -

\section{REFERENCES}

1. Véliz Martínez PL, Jorna Calixto AR, Berra Socarrás EM. Identificación y normalización de las competencias profesionales específicas del especialista en Medicina Intensiva y Emergencia. Educ Med Sup [Internet]. 2015 [cited 2015 Jul 27];29(2). Available from: http://ems.sld.cu/index.php/ems/article/ view/582. Spanish

2. Perdomo Victoria I, Martínez Calvo S. Estrategia metodológica para evaluar competencias profesionales en especialistas de Higiene y Epidemiología. Rev Cubana Salud Pública [Internet]. 2010 May-Jun [cited 2015 Feb 19];36(2):142-7. Available from: http://scielo.sld .cu/scielo.php?script=sci_arttext $\&$ pid $=$ S0864 $-34662010000200007 \&$ Ing $=$ es\&nrm=iso\&tlng= es. Spanish.

3. Salas Perea RS. Propuesta de estrategia para la evaluación del desempeño laboral de los médicos en Cuba [thesis]. [Havana]: National School of Public Health (CU); 2009. Spanish.

4. Roca J, Pérez JM, Colmenero $M$, Muñoz $H$, Alarcón L, Vázquez G. Competencias profesionales para la atención al paciente crítico: Más allá de las especialidades. Med Intensiva. 2007;31(9):473-84. Spanish.

5. González Jaramillo S, Ortiz García M. Las competencias profesionales en la Edu- cación Superior. Educ Med Super [Internet]. 2011 Jul-Sep [cited 2015 May 3];25(3):334-43. Available from: http://scielo .sld.cu/scielo.php?script=sci_arttext\&pid=S0864 $-21412011000300011 \&$ Ing=es. Spanish.

6. Windsor C, Douglas C, Harvey T. Nursing and competencies - a natural fit: the politics of skill/competency formation in nursing. Nursing Inquiry [Internet]. 2012 Sep [cited 2015 Nov 10];19(3):213-22. Available from: http://onlinelibrary.wiley.com/doi/10.1111/j.1440 $-1800.2011 .00549 . x / a b s t r a c t$

7. Véliz Martínez PL, Jorna Calixto AR, Berra Socarrás EM. Consideraciones sobre los enfoques, 
definiciones y tendencias de las competencias profesionales. Educ Med Super [Internet]. 2016 [cited 2016 Jul 23];30(2). Available from: http://www.ems .sld.cu/index.php/ems/article/view/812. Spanish

8. González-Montero MG, Lara-Gallardo PM, González-Martínez JF. Modelos educativos en medicina y su evolución histórica. Rev Esp Med Quir [Internet]. 2015 [cited 2015 Nov 18];20:25665. Available from: http://www.redalyc.org/ html/473/47345917022/. Spanish.

9. Martínez Manrique R, Iglesias Quevedo RR. La formación de los recursos humanos en base a competencias profesionales. Un aporte para la elevación de la gestión económico-financiera en las empresas y unidades presupuestadas. Santiago. 2005;107:43-57. Spanish.

10. Ortiz-García M, Vicedo-Tomey A, RodríguezRivaltas I, Sardiñas-Arce ME. Propuesta de competencias profesionales específicas para el perfil del egresado en Pediatría en Cuba. Rev Habanera Ciencias Médicas [Internet]. 2015 [cited 2015 Oct 3];14(4):516-26. Available from: http://www.revha banera.sld.cu/index.php/rhab/article/view/578. Spanish.

11. Escobar García MC, Quindemil Torrijo EM, Rumbaut León F, Pelegrín Entenza N. Diseño Curricular por Competencias en la Titulación de Bibliotecología y Ciencias de la Información en la Universidad Técnica de Manabí. Int Multilingual J Contemporary Res [Internet]. 2014 Jun [cited 2015 Oct 3];3(1):81-8. Available from: http://imjcr .com/journals/imjcr/Vol_3_No_1_June_2014/9 .pdf. Spanish.

12. Salgado $F$, Corrales J, Muñoz L, Delgado J. Design of course programs based on competences and their application at the Universidad del Bío-Bío, Chile. Ingeniare Rev Chilena Ingeniería [Internet]. 2012 Aug [cited 2015 Oct 6];20(2):267-78. Available from: http://www.sci elo.cl/scielo.php?script=sci arttext\&pid=S0718 $-33052012000200013 \&$ Ing=es\&tlng=en. Spanish.

13. Tupesis JP, Jacquet GA, Hilbert SL, Pousson A, Khanna K, Ross J, et al. The role of graduate medical education in global health: Proceedings from the 2013 Academic Emergency Medicine Consensus Conference. Acad Emerg Med [Internet]. 2013 Dec [cited 2015 Nov 7];20(12):1216-23. Available from: http://onlinelibrary.wiley.com/doi/10.1111/acem .12260/abstract

14. The CoBaTrICE Collaboration, Bion JF, Barrett $\mathrm{H}$. Development of core competencies for an international training programme in intensive care medicine. Intensive Care Med. 2006 Sep;32(9):1371-83

15. Buckley JD, Addrizzo-Harris DJ, Clay AS, Curtis JR, Kotloff RM, Lorin SM, et al. Multisociety task force recommendations of competencies in pulmonary and critical care medicine. Am J Respir Crit Care Med [Internet]. 2009 Aug 15 [cited 2015 Oct 23];180(4):290-5. Available from: http://www .atsjournals.org/doi/full/10.1164/rccm.200904 -0521ST\#.Us0Ydfsvm 0

16. Oficina Nacional de Normalización (CU) [Internet]. Havana: Oficina Nacional de Normalización (CU); c2016. Norma cubana 3000; 2007 May [cited 2015 Jun 10]. Available from: http://www .nc.cubaindustria.cu. Spanish.

17. Oficina Nacional de Normalización (CU) [Internet]. Havana: Oficina Nacional de Normalización (CU); c2016. Norma cubana 3001; 2007 May [cited 2015 Jun 10]. Available from: http://www .nc.cubaindustria.cu. Spanish.

18. Oficina Nacional de Normalización (CU) [Internet]. Havana: Oficina Nacional de Normalización (CU); c2016. Norma cubana 3002; 2007 May [cited 2015 Jun 10]. Available from: http://www .nc.cubaindustria.cu. Spanish.

19. Urbina Laza O. Metodología para la evaluación de las competencias laborales de los profesionales de enfermería que laboran en servicios de neonatología [thesis]. [Havana]: National School of Public Health (CU); 2007. Spanish.
20. Oramas González R, Jordán Severo T, Valcárcel Izquierdo N. Competencias y desempeño profesional pedagógico hacia un modelo del profesor de la carrera de Medicina. Educ Méd Super [Internet]. 2013 Jan-Mar [cited 2015 Oct 10];27(1):123-34. Available from: http://scieloprueba.sld.cu/scielo.php?script=sci_arttext\&pid= S086421412013000100015\&lng=es. Spanish.

21. Salas Perea RS, Díaz Hernández L, Pérez Hoz G. Identificación y diseño de las competencias laborales en el Sistema Nacional de Salud. Educ Méd Super [Internet]. 2013 Mar [cited 2015 Sep 29];27(1):92-102. Available from: http://scielo .sld.cu/scielo.php?script=sci_arttext\&pid=S0864 $-21412013000100012 \&$ Ing=es. Spanish.

22. Véliz Martínez PL, Jorna Calixto AR. Evolución histórica y perspectivas futuras de la Medicina Intensiva y Emergencia como especialidad en Cuba. Educ Méd Super [Internet]. 2014 [cited 2015 Sep 29];28(3). Available from: http://ems.sld.cu/index .php/ems/article/view/355. Spanish.

23. Véliz PL, Berra EM, Jorna AR. Definition of specific functions and procedural skills required by Cuban specialists in intensive care and emergency medicine. MEDICC Rev [Internet]. 2015 Jul [cited 2015 Oct 3];17(3):18-26. Available from: http://www.medicc.org/mediccreview/index.php? issue $=35 \&$ id $=468 \& a=v a$

24. Torres Esperón M. Metodología para definir funciones profesionales. Rev Cubana Salud Pública [Internet]. 2008 Oct-Dec [cited 2015 Mar 7];34(4). Available from: http://scielo.sld .cu/scielo.php?script=sci arttext\&pid=S0864 $-34662008000400017 \&$ Ing $=\bar{e}$. Spanish.

25. Artiles Visbal L, Iglesias Otero J, Barrios Osuna I. Metodología de la investigación para las ciencias de la salud. Havana: Editorial Ciencias Médicas; 2009. Spanish.

26. Reglamento para la obtención del segundo grado de las especialidades en ciencias de la salud. Resolución Ministerial No. 132/2009. Havana: Ministry of Public Health (CU); 2009. Spanish.

27. Irigoin M, Vargas F. Competencia laboral: manual de conceptos, métodos y aplicaciones en el sector salud. Montevideo: Cinterfor-Pan American Health Organization; 2002. Spanish

28. Ortiz García M, Cires Reyes E. Diseño curricular por competencias. Aplicación al macrocurrículo. Rev EDUMECENTRO [Internet]. 2012 Jan-Apr [cited 2015 Oct 10];4(1):10-7. Available from: http://scie lo.sld.cu/scielo.php?script=sci_arttext\&pid=S2077 $-28742012000100003 \&$ Ing=es. Spanish.

29. Véliz Martínez PL, Berra Socarrás EM, Jorna Calixto AR, Sabina Martínez RR. Aplicación del método Delphi para la definición de funciones del especialista en medicina intensiva y emergencia. Rev Cubana Med Intensiva Emerg [Internet]. 2013 [cited 2015 Mar 18];12(2). Available from: http://bvs.sld.cu/re vistas/mie/vol12_2_13/mie03213.html. Spanish.

30. Caballero-López $\bar{A}$. ¿Qué es un intensivista en Cuba? Rev Cubana Med Intensiva Emerg [Internet]. 2008 [cited 2015 Sep 13];7(4). Available from: http://www.bvs.sld.cu/revistas/mie/vol7_4_08/ mie10408.htm. Spanish.

31. Valdés-Suárez O. Intensivista; ¿título o profesión? Rev Cubana Med Intensiva Emerg [Internet]. 2015 [cited 2016 Feb 7];15(1). Available from: http:// www.revmie.sld.cu/index.php/mie/article/view/128. Spanish.

32. Espinosa Brito A, Rocha Hernández JF. Medicina clínica para intensivistas. Preguntas a un experto. Rev Cubana Med Intensiva Emerg [Internet]. 2007 [cited 2012 May 16];6(4). Available from: http:// bvs.sld.cu/revistas/mie/vol6_4_07/mie09407.htm. Spanish.

33. Valdés-Suárez $\mathrm{O}$. La medicina interna y el método clínico: pasado, presente y futuro. Rev Cubana Med Intensiva Emerg [Internet]. 2014 [cited 2016 Feb 7];13(4). Available from: http://www.revmie.sld .cu/index.php/mie/article/view/41. Spanish.

34. Bembibre Taboada RM. Aspectos éticos-bioéticos en la atención del paciente crítico. Rev Cubana
Med [Internet]. 2003 Jan-Mar [cited 2015 Dec 1];42(1):5-11. Available from: http://scielo.sld .cu/scielo.php?script $=$ sci arttext\&pid=S0034 $-75232003000100001 \&$ lng=es. Spanish.

35. Alonso Mariño AL, Alonso Mariño OL, López Rodríguez EF. Dilemas éticos de las decisiones médicas en cuidados intensivos. Acta Médica del Centro [Internet]. 2014 [cited 2015 Dec 1];8(1):37-45. Available from: http://www.revactamedicacentro.sld.cu/ index.php/amc/article/view/43. Spanish.

36. Hernández Ortiz J, Gómez Torres D. Una aproximación al concepto de gerencia y administración aplicado a la disciplina de enfermería. Esc Anna Nery [Internet]. 2010 Jul-Sep [cited 2015 Apr 26];14(3):625-32. Available from: http://www.scielo .br/pdf/ean/v14n3/v14n3a27.pdf. Spanish.

37. Blanch L, Annane D, Antonelli M, Chiche JD, Cuñat J, Girard TD, et al. The future of intensive care medicine. Med Intensiva. 2013 Mar;37(2):91-8.

38. Sandianes B, Sánchez N. Metodología para la Gestión del Proceso de Categorización del Potencial Científico en Organizaciones de $1+D+1$. XIV Congreso Latino-lberoamericano de Gestión Tecnológica - ALTEC 2011. 2011 Oct 19-21; Lima, Perú. Biblioteca Digital de la Asociación LatinoIberoamericana de Gestión Tecnológica [Internet]. 2013 [cited 2016 Feb 7]. Available from: http://www .altec-dl.org/index.php/altec/article/view/2198/21 98. Spanish.

39. Programa de Especialización en Medicina Intensiva y Emergencias. Havana: Ministry of Public Health (CU); 1999. Spanish.

40. Blanco Aspiazu MA, Rodríguez Silva $\mathrm{H}$, Moreno Rodríguez MA, Díaz Hernández L, Salas Perea RS Del Pozo Jerez H, et al. Propuesta de competencias profesionales para el perfil del egresado en la especialidad de medicina interna en Cuba. Rev Habanera Cienc Méd [Internet]. 2015 Dec [cited 2016 Jan 25];14(6):823-38. Available from: http://scielo .sld.cu/scielo.php?script=sci arttext\&pid=S1729 $-519 X 20150006000128$ Ing $=e s$. Spanish.

41. Lineamientos de la política económica y social del Partido y la Revolución. In: VI Congreso del Partido Comunista de Cuba. Capítulo VI Política Social. Aprobado el 18 de Abril de 2011. Havana: Government of the Republic of Cuba. Spanish.

\section{THE AUTHORS}

Pedro L. Véliz-Martínez (Corresponding author: urgrav@infomed.sld.cu), dual specialist in internal medicine and intensive care \& emergency medicine, with master's degrees in urgent care medicine and medical education. Associate professor and researcher, Medical University of Havana, Cuba.

Ana R. Jorna-Calixto, family physician with a master's degree in health nutrition. Associate professor and adjunct researcher, National School of Public Health, Havana, Cuba.

René Oramas-González, family physician with a master's degree in medical education and doctorate in pedagogical sciences. Full professor and associate researcher, Medical University of Havana, Cuba.

Submitted: March 11, 2016

Approved for publication: September 3, 2016 Disclosures: None 